\title{
Present status of gayal (Bos frontalis) in the home tract of Bangladesh
}

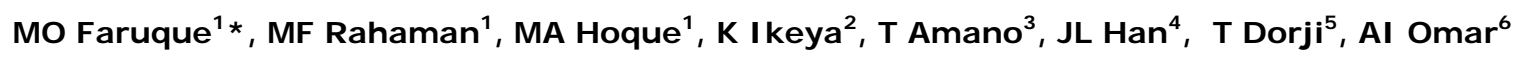

${ }^{1}$ Department of Animal Breeding, Bangladesh Agriculture University, Mymensingh 2202, Bangladesh; ${ }^{2}$ National Museum of Ethnology, Suita, Osaka 565-8511, Japan; ${ }^{3}$ Faculty of Animal Health Technology, Yamazaki Gakuen University, 4-7-2 Minami-Osawa, Hachiouji, Tokyo 192-0364, Japan; ${ }^{4}$ Institute of Animal Science, Chinese Academy of Agricultural Sciences, Yuan Ming Yuan Xi Lu, Haidian, Beijing 1000193, PR China; ${ }^{5}$ International Centre for Integrated Mountain Development, Khumaltar, Lalitpur, Kathmandu, Nepal; ${ }^{6}$ Laboratory of Animal Genetics, Breeding and Reproduction, College of Animal Science and Technology, Huazhong Agricultural

University, Wuhan 430070, PR China

\begin{abstract}
Gayal (Bos frontalis) is a semi domesticated and endangered bovine species in Bangladesh. This study was conducted to know the present distribution, performances and utility of gayal in the home tract. Bandarban Hill district was found the home tract of gayal in Bangladesh. Gayals were reared under extensive management system in the forest of Bandarban Hill district. They browsed forest herbs and grass freely in the forest and came to human dwelling for salt licking. Total number of gayal was counted between 800-900. The average number of gayal per farmer was 5.01. The coat color of adult gayal was black. White stocking was very prominent in adult gayal. The height at wither and weight for adult males ranged from 126 to $136 \mathrm{~cm}$ and 490 to $577 \mathrm{~kg}$, respectively. Reproductive efficiency was high and calving interval was 402 days. They exhibited high disease resistant. The PVC (Pack Cell Volume) and hemoglobin value was $33.5 \pm 5.71 \%$ and $13.43 \pm 2.9 \mathrm{~g} / \mathrm{dl}$, respectively. Gayal was used only as meat animal. The high growth rate and reproductive efficiency of gayal in the home tract indicates that this species can be utilized economically if proper breeding plan and sound extension service can be adopted.
\end{abstract}

Key words: Gayal, home tract, distribution, phenotypes, utility, Bangladesh

Bangladesh Animal Husbandry Association. All rights reserved.

Bang. J. Anim. Sci. 2015. 44 (1): 75-84

\section{I ntroduction}

The gayal (Bos frontalis), synonymous with mithan and mithun, is a unique bovine species. Gayal is a semi-wild animal and originated from cross between gaur and domestic cattle (Simoons and Simoons 1968, Tanaka et al. 2011). The gayal is found in the hilly areas of Bhutan, eastern India, eastern Bangladesh, northern Myanmar, and northwestern Yunnan, China with altitude up to $3000 \mathrm{~m}$ (Simoons and Simoons 1968, Faruque et al. 1985; Mason 1988; Payne and Hodges 1997; Li et al. 2008; Mondol et al. 2014). In the moist forests of hills, gayal is a free-ranging animal without planned breeding. It is sometimes described as semi-wild or semidomestic animal (Scherf 2000). In Bangladesh, it is found only in the Bandarban Hill district. Gayal is a valuable sacrificial animal and regarded as a symbol of social status of tribal people in Bangladesh and India (Simoons and Simoons
1968, Furer-Haimendorf 1980; Brauns and Loffler 1986). In Bhutan, Thrabum (native cattle) is traditionally used for hybridization with gayal (mithun) to produce hybrid, which is preferred for dairy and draught purposes (Hickman and Tenzin 1982; Winter et al. 1986). Gayal (Mithun) is an extremely efficient grazer on steep hilly slopes compared to other animals. Gayal is primarily reared as meat animal and highly preferred among the tribal people of north-eastern region of India. Nevertheless, gayal is also used as a ceremonial animal and plays important role in economical, social and cultural life of the tribal people of north-eastern India. Like buffalo, gayal milk contains high protein and fat. It is evident that gayal $x$ cattle hybrid is used as milk animal in some pockets of north-eastern India and Bhutan. Therefore, this species may also be explored as a supplementary component of milk production system in the region. Besides, it is 
now established that superior quality leather can be obtained from Mithun skin (Mondal et al. 2014). Gayal is also used as a ceremonial animal and plays important role in economical, social and cultural life of some tribal people in Bandarban Hill district and Chittagong district in Bangladesh. Scientific study on gayal in Bangladesh started in 1985 with the work of Namikawa et al. (1987). The ex situ conservation and improvement program of this species was undertaken by Bangladesh Livestock Research Institute in 1990 (Haque et al. 2001). The program involved onstation performances and adaptability study of gayal and gayal x Holstein hybrid. However, no fruitful result could be generated yet from that program. Except the report of Furer-Haimendorf (1980), no scientific report is available on the status and performances of gayal in the home tract of Bangladesh. In fact, gayal is now one of the endangered animal genetic resources in Bangladesh (Faruque et al. 2010) and measure should be taken to conserve this species through its economic utilization. The present study was, therefore, undertaken to find out the present stock position of gayal, their geographical distribution, morphology, production system and utility in their home tract. The aim was to find out the status and utility of gayal in situ for better utilization in future.

\section{Materials and Method}

Field survey was conducted in different areas of Bandarban Hill district with the help of respective local Livestock Offices and local tribal people. The goal was to know the geographical distribution of gayal, its production environment and system in home tract. 10 field trips were made from April 2008 to December 2012. Tanchi, Ruma and Royangchhari upazila were found the home tract of gayal (Figure 1). In the middle of 2011, 20 gayals of two tribal villages near the Bangladesh and Myanmar boarder in Ruma Upazila were selected for recording the morphology and production traits of gayal. Through the field trips and animal recording, the following information was collected:

$>$ Ecology and vegetation patter of home tract of gayal

$>$ Total number of gayal in the home tract

$>$ Morphology of gayal (Coat color, body measurement, body conformation)

$>$ Feeds and Feeding behavior

$>$ Reproductive parameters

$>$ Incidence of diseases and fitness

$>$ Utility of gayal.

The body measurement was done by animal measuring scale and weight was taken by Holstein cattle weighing tape. Blood samples were collected from a number of individuals using venoject tubes, carried to Animal Genetics laboratory, Bangladesh Agricultural University, Mymensingh. The blood was used to determine packed cell volume (PCV) and Haemoglobin ( $\mathrm{Hb}$ ) concentration. The PCV was estimated by use of hematocrit. Haemoglobin value was measured by acid hematin method with the help of Haemometer. Faeces were also collected from a number of individuals, carried to Parasitology laboratory, Bangladesh Agricultural University, Mymensingh to find out faecal eggs of gastrointestinal parasites. A modified McMaster technique was used to determine faecal eggs and to identify different ova and oocyst of nematode species following Cable (1957). Data was analyzed statically after Snedechor and Cockran (1980).

Information on morphology and production traits of gayal was also collected from Bhutan and Yunnan province of China in the year of 2011 and 2012 respectively through two field trips. These data were used to determine the purity of gayal in home tract of Bangladesh.

\section{Results}

\section{The home tract of Gayal: Bandarban Hill district}

The home tract of gayal in Bangladesh was found to be Bandarban Hill district (Figure 1). Bandarban Hill district, located in the southeastern part of Bangladesh, is one of the three hill districts of Bangladesh. It lies between $21^{\circ} 11^{\prime}$ and $22^{\circ} 30^{\prime}$ north latitude and between $92^{\circ} 04^{\prime}$ and $92^{\circ} 41^{\prime}$ east longitude. Bandarban Hill district (area $4,479 \mathrm{~km}^{2}$ ) is not only the remotest district of the country, but also the least populated one (population 300740). It is bounded on the north by Rangamati district, on the east by Myanmar, on the south by Myanmar 
and on the west by Cox's Bazar district and Chittagong district. Bandarban Hill district consists of mostly forests and hills. The four major mountain ranges of the district are the Meranja, Wailatong, Tambang and Politai. The two highest peak of Bangladesh - Tahjindong $(1280 \mathrm{~m})$, and Keokradong $(1230 \mathrm{~m})$ - are located in Bandarban Hill district. Annual average maximum and minimum temperature of Bandarban Hill district are $34.6^{\circ} \mathrm{C}$ and $13.0^{\circ} \mathrm{C}$ respectively. Annual rain fall is $3031 \mathrm{~mm}$.

The present study revealed that the hills and cliffs were covered with dense bamboo breaks, tall trees and creeper jungles. The valleys were covered with thick forest (Plate 1). The vegetation was characterized by semi-evergreen (deciduous) to tropical evergreen tall trees belonging to dipterocarpaceae, euphorbiaceae, lauraceae, leguminacae and rubiaceae. Most of the hills were also covered with a kind of grass known as shan.

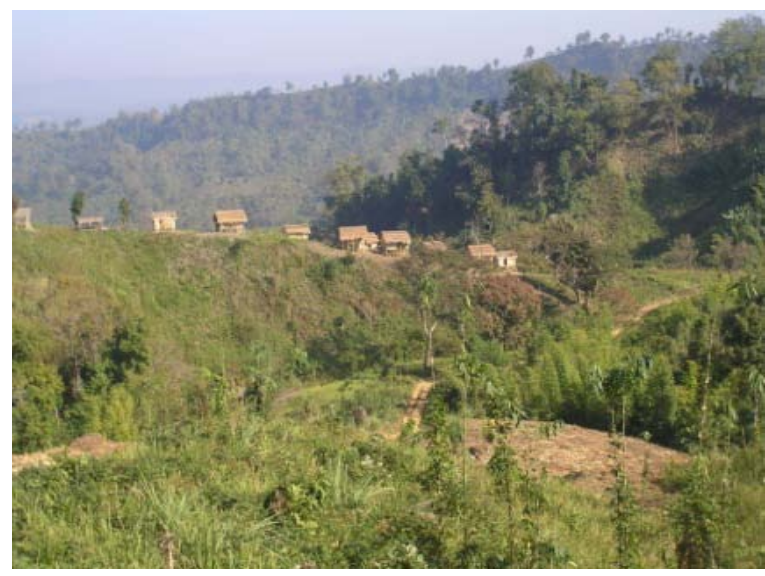

Plate 1. Topography, Vegetation pattern and dwelling in the Bandarban Hill district

\section{I nhabitant of Gayal}

The survey revealed that gayal lived in the deep forest in the hill of Bandarban Hill district near Bangladesh - Myanmar boarder and BangladeshMizoram boarder (Plate 2). They were found in Royangchhari, Ruma, Thanchi and Naikhonchhari Upazila of Bandarban Hill district and Bilaichhari Upazila of Rangamati Hill district. They were, however, found in large number in Royangchhari, Ruma, Thanchi which were the actual home tract of gayal nowadays. The elevation was found to range from $600 \mathrm{~m}$ to $1100 \mathrm{~m}$. These areas were covered by deep forest and inaccessible by any type of vehicle, but accessible only by foot. Fig 3 shows the inhabitant of gayal in the forest of Ruma and Royangchhari.

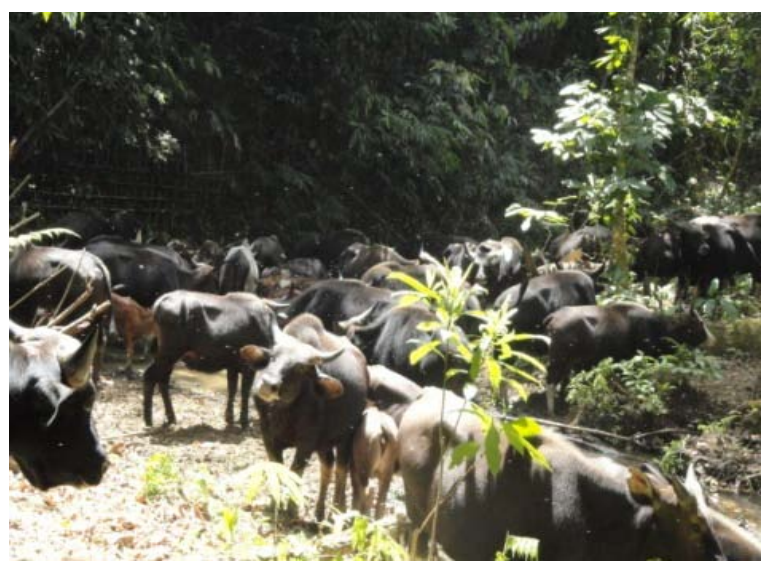

Plate 2. Gayal in the forest of Bandarban Hill district

\section{Distribution of Gayal in home tract}

In depth field survey was made to find out the distribution pattern and actual number of Gayal in Bandarban Hill district. Survey was conducted in Ruma, Thanchi and Naikhonchhari Upazila known as the home tract of gayal. The survey was conducted to find out house-hold gayal number, system of gayal production and identifying the problems related to gayal production. The survey revealed that only Bawm, Marma and Mru tribes possessed gayal in Ruma Upazila. In Royangchhari Upazila, Bawm, Marma and Tanchonga tribes possessed gayal. In Tanchi, Marma and Mru tribes possessed gayal. Bawm called it as "Siya", and the Marma called it as "Tong Noa". Mro called it as "Chia nom". A Total of 571 gayals could be counted in three upazila during this study. The average number of gayal per household was found to be 5.01. The minimum and the maximum number of gayal per household was 1 and 25, respectively. The detail has been presented in Table 1 .

Table 1. Number of gayal in different upazila of Bandarban Hill district

\begin{tabular}{lccccc}
\hline Upazila & No. house hold & Total & Cow & Bull & Calves \\
\hline Ruma & 76 & 392 & 195 & 60 & 137 \\
Royangchhari & 19 & 69 & 32 & 14 & 23 \\
Tanchi & 19 & 110 & 54 & 18 & 38 \\
\hline Total & $\mathbf{1 1 4}$ & $\mathbf{5 7 1}$ & $\mathbf{2 8 1}$ & $\mathbf{9 2}$ & $\mathbf{1 9 8}$ \\
\hline
\end{tabular}




\section{Morphology of Gayal}

Gayal had typical appearance. The head, at the upper part, was very broad and flat, and was contracted suddenly towards the nose, which was naked, like that of the common cow. From the upper angle of the forehead proceeded two thick, short, horizontal horns, which were smooth and lied nearly in the plane of the forehead. They diverged outward, and turned upward with a gentle curve. At the bases, they were very thick, and are slightly compressed. The neck was very slender near the head, at some distance from which a dewlap commenced. In place of the hump, the Gayal had a sharp ridge. The tail was covered with short hair, except near the end, where it had a tuft like that of the common ox. The legs, especially the fore ones, were thick. The hinder parts were weaker in proportion than the fore one owing to the contraction of the belly.

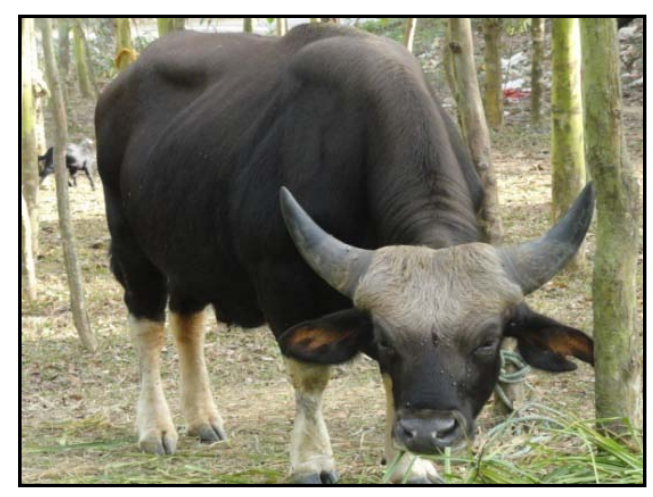

Plate 3a. An adult gayal: Black coat color with white stock

The coat color of adult gayal was black (Plate 3a). In some adult gayal, white spotting of various degrees in different parts of the body was observed (Plate $3 b$ ). White stocking in the lower part of the legs was present in all adult gayal.

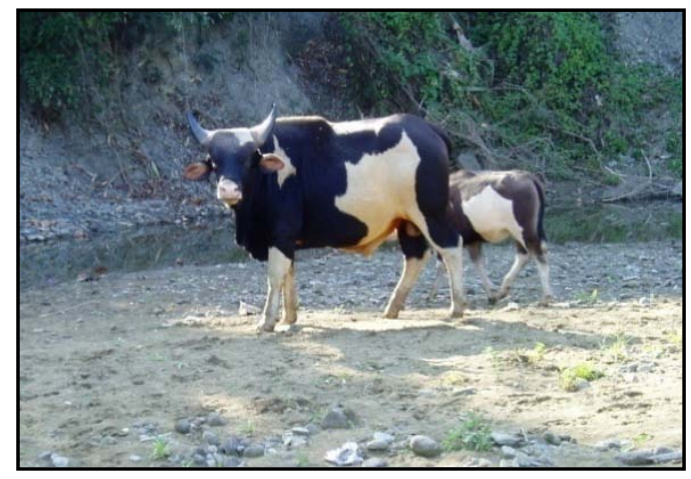

Plate $3 \mathbf{b}$. An adult gayal: Black coat color with white spotting
This white stocking developed at 4 months age in gayal. The coat colour of new born calf was red or coffee color (Plate $4 \mathrm{a}$ ). The coat color of calf turned black after 4 months of age (Plate $4 b$ ).

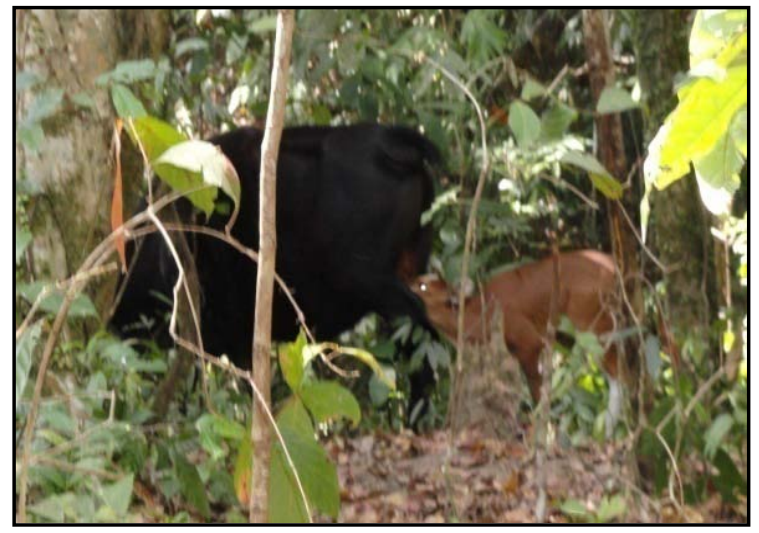

Plate 4a. A gayal cow with red coat colored new born calf

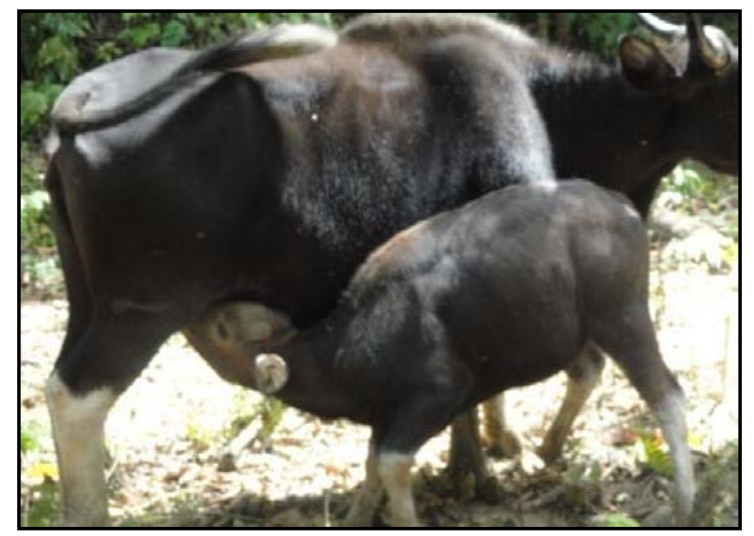

Plate 4b. A gayal cow with black coat colored 4-month old calf

The body measurements and weight of 10 gayals could be taken in the home tract. Average body measurements and weight have been presented in Table 2. The average height at wither, body length, head length, forehead breath and weight of mature bulls ( $5-6$ years old) were $132.50 \pm 1.42$ $\mathrm{cm}, \quad 132.00 \pm 1.02 \mathrm{~cm}, 50.00 \pm 0.00 \mathrm{~cm}$, $32.22 \pm 0.55 \mathrm{~cm}$ and $510.00 \pm 16.71 \mathrm{~kg}$, respectively. The average height at wither, body length, head length, forehead breath and weight of growing gayal (1-2 years old) were $120.75 \pm 0.42 \mathrm{~cm}, 124.50 \pm 0.25 \mathrm{~cm}, 45.50 \pm 0.25$ $\mathrm{cm}, 30.00 \pm 0.00 \mathrm{~cm}$ and $2.43 .33 \pm 11.96 \mathrm{~kg}$, respectively. 


\section{Status of Gayal in Bangladesh}

Table 2. Average body measurements \pm standard errors and weight of gayal in the home tract

\begin{tabular}{cccccccc}
\hline $\begin{array}{c}\text { Sl. } \\
\text { No. }\end{array}$ & $\begin{array}{c}\text { Age } \\
\text { (year) }\end{array}$ & Sex & $\begin{array}{c}\text { Wither } \\
\text { height } \\
(\mathrm{cm})\end{array}$ & $\begin{array}{c}\text { Body } \\
\text { length } \\
(\mathrm{cm})\end{array}$ & $\begin{array}{c}\text { Head } \\
\text { length } \\
(\mathrm{cm})\end{array}$ & $\begin{array}{c}\text { Forehead } \\
\text { breath } \\
(\mathrm{cm})\end{array}$ & $\begin{array}{c}\text { Weight } \\
\mathrm{Kg})\end{array}$ \\
\hline 1 & $1.2-2.0$ & Male & 120.75 & 124.50 & 45.50 & 30.00 & 243.33 \\
& $(2)$ & & \pm 0.42 & \pm 0.25 & \pm 0.25 & \pm 0.00 & \pm 11.96 \\
\hline 2 & 2.0 & Female & 120.00 & 124.00 & 46.00 & 30.00 & 260.00 \\
& $(2)$ & & \pm 0.00 & \pm 0.00 & \pm 0.00 & \pm 0.00 & \pm 5.01 \\
\hline 3 & $5-6$ & Male & 132.50 & 132.00 & 50.00 & 32.33 & 510.00 \\
& $(6)$ & & \pm 1.42 & \pm 1.02 & \pm 0.00 & \pm 0.55 & \pm 16.71 \\
\hline
\end{tabular}

Figures in the parenthesis indicate the number of observation

In order to identify the true gayal, information was collected from Bhutan (from Bhutanese government gayal farm) and China (from Kunming zoo). This information was used to compare the gayal among the countries (Plate 5). The gayal of Bangladesh resembled to those of China. It also resembled to gayal of Bhutan except the forehead. The forehead of gayal in Bhutan was wider than that of gayal in Bangladesh.

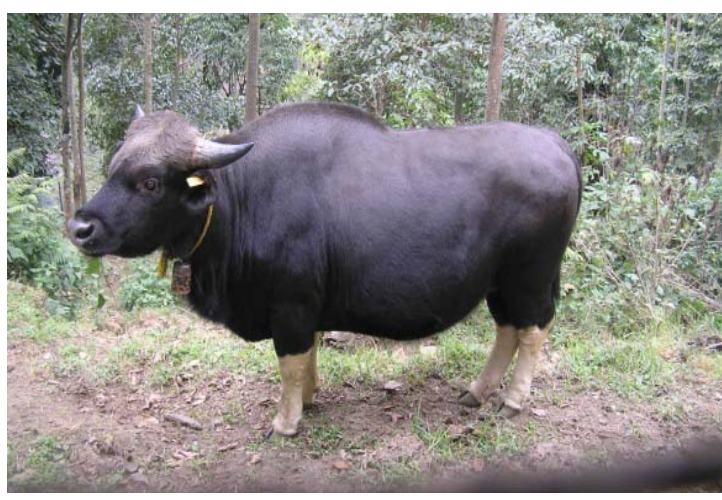

Plate 5a. Gayal of Butan

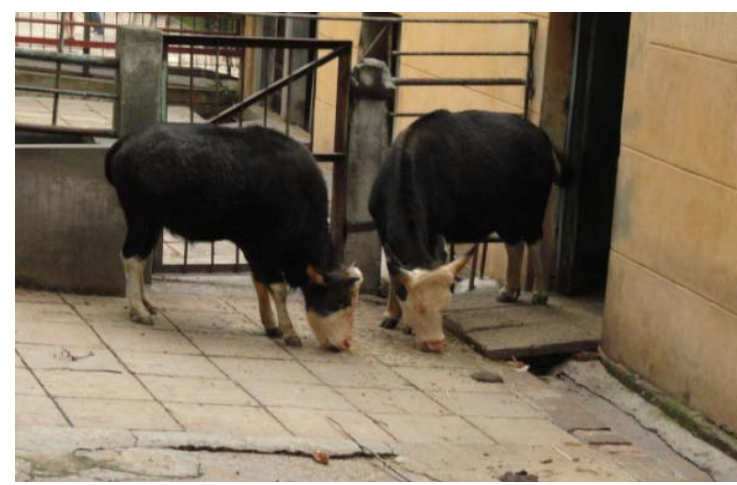

Plate 5b. Gayal of China
The intercrossing of gayal and native zebu cattle occurred in some cases. The variation in morphology of pure gayal and gayal hybrid was more prominent in the stocking color, head shape and horn pattern. Hybrid lacked white stocking, had thin horn and less body size and weight. The plate 6 represents such a hybrid cow.

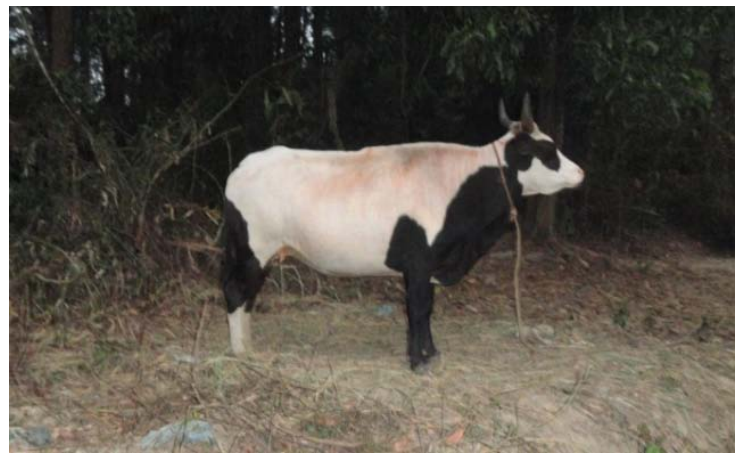

Plate 6. A gayal hybrid cow in Ruma

\section{Feeds and Feeding Behavior of Gayal}

The feeds of gayal consisted of naturally grown shrubs and grass in the forest. The hill bamboo leaves and hilly grass were the main feeds. Gayal roamed in the forests of hills and moved from hill to hill for browsing feeds and drinking water (Plate $7 \mathrm{a}$ and $7 \mathrm{~b}$ ).

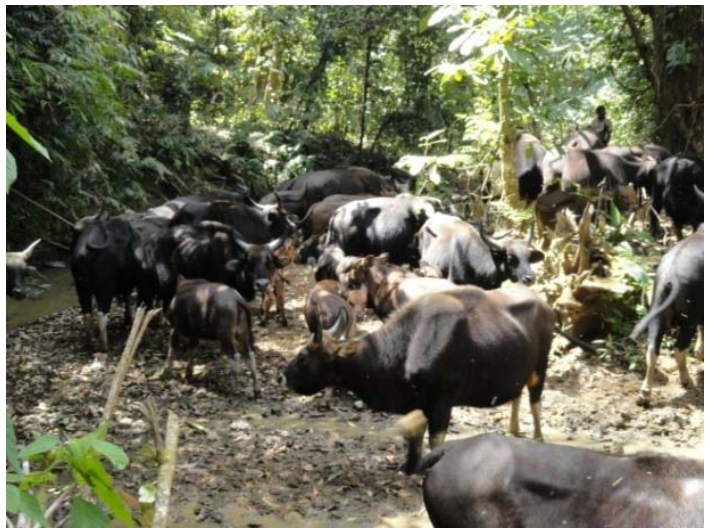

Plate 7a. Gayal were grazing in the forest

In most cases, they stayed in the forest even in the night. For water, they traveled to small canal running through the hills. They grazed for feeds in the morning and afternoon, drunk water between $10.00 \mathrm{am}$ to 12.00 noon. In the noon, they took rest under trees near the water holds or nearby human dwelling. They came to the owner dwelling for feeding common salt at weekly or 
fortnightly interval. If the grazing place was far away from owner dwelling, the owner traveled to gayal inhabitant for feeding common salt (Plate 8).

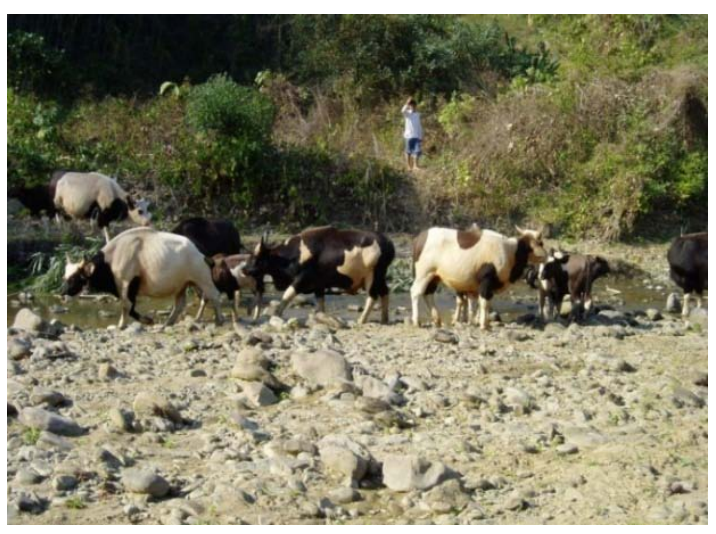

Plate 7b. Gayal were drinking in the cannel

\section{Production and health status in the home tract}

The production system of gayal was found to be extensive management system. The animals moved freely in the forests and took rest in the night in the forest too. Sometimes they stayed nearby village in an open area. They were not kept confined and no feed was supplemented. However, they were found to graze in limited area of forest as the forest was fenced by the gayal owner so that the owner could trace the gayal. That system restricted the free movement of gayal from hill to hill as happened in the past. Another disadvantage of that system was that feed resources of gayal became restricted.

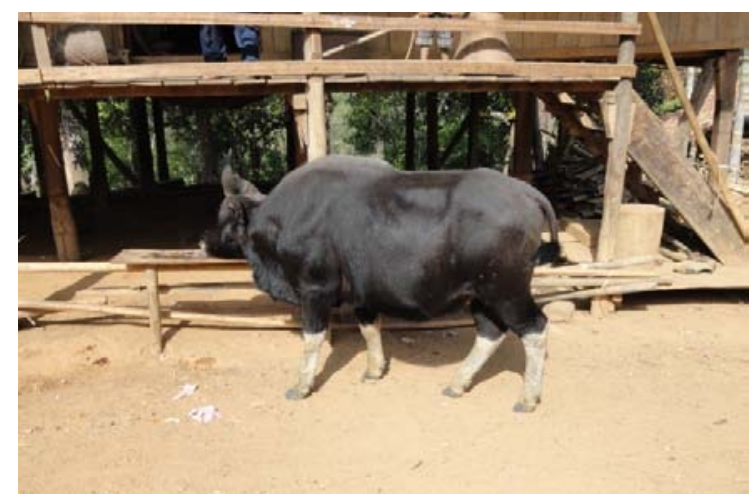

Plate 8. Gayal was feeding common salt in human dwelling in the forest
Information on some important parameters was collected during this study. The mature weight of adult males has been presented in Table 2. Table 4 provides the birth weight of gayal calves. The average birth weight of calves was $20.85 \pm 0.24$ $\mathrm{kg}$. The average birth weights of male and female calves were $21.67 \pm 0.15$ and $19.63 \pm 0.21 \mathrm{~kg}$, respectively. The growth rate was quite high ( 256 $\mathrm{gm} /$ day) as revealed through the weight of Gayal (Table 2 and Table 3). This study revealed that the reproductive efficiency of gayal cows were high as indicated by calving interval. The calving interval was found to be $402.85 \pm 3.04$ days. Considering the gestation period of $296.25 \pm 0.77$ days (Table 3 ), this feature of calving interval was a indicator for good reproductive efficiency. All the cows were subjected to natural mating and had the access to enough green forage. These two factors perhaps contributed high reproductive efficiency (One calf per year) in the home tract. However, the size of gayal was decreasing gradually as mentioned by the gayal owners. Perhaps continuous inbreeding within the herd of gayal has resulted in gradual decrease in size. Milking from gayal was not practiced anywhere. Calves were allowed to suckle full milk of dam. Neither male nor female gayal was used for any sort of draught work. Gayal was found to be used only as meat animal.

Table 3. Some economic parameters of gayal in the home tract

\begin{tabular}{lc}
\hline Parameter & Value (mean_SE) \\
\hline Birth weight $(\mathrm{kg})(10)$ & $20.85 \pm 0.24$ \\
Male calves $(\mathrm{kg})(6)$ & $21.67 \pm 0.15$ \\
Female calves $(\mathrm{kg})(4)$ & $19.63 \pm 0.21$ \\
Gestation length (day) (7) & $296.25 \pm 0.77$ \\
Calving interval (day) (4) & $402.85 \pm 3.04$ \\
\hline
\end{tabular}

Figures in the parenthesis indicate the number of observation

Table 4. Packed cell volume and haemoglobin of gayal in the home tract

\begin{tabular}{llcc}
\hline Age (years) & Sex & Packed cell volume \% & Haemoglobin g/dl \\
\hline $3.0-5.0(6)$ & Male & $33.5 \pm 5.71$ & $13.43 \pm 2.9$ \\
& & (22 to 36) & (8.8 to 16.7) \\
\hline $0.5(2)$ & Female & 34.5 & 12.2 \\
& & (34 to 35) & (10.4 to 14.0) \\
\hline
\end{tabular}

Figures in the parenthesis indicate the number of observation 
Gayal in the natural condition was found healthy. The percent of packed cell volume values and haemoglobin values have been presented in Table 4. Feces analyzed indicated that Gayal was almost free from major internal parasites. There was no outbreak of Foot and Mouth disease or any other contagious disease during this study period. Some gayal was affected by Conjunctivitis. Few Gayals were injured during grazing in the forest. The animals were treated by village unqualified doctors as the veterinary service was not available due to difficult communication system.

\section{Marketing}

There was no market for selling or buying gayal in Bandarban Hill district. The owners of gayal did not sell any healthy gayal cow or calf during this study period. They sold only mature gayal bulls and culled cows. Those gayal bulls were sold between December to February and used as sacrificed animals for the Muslim religious festival called "Oros" organized by the Muslim "peer" (Plate 9).

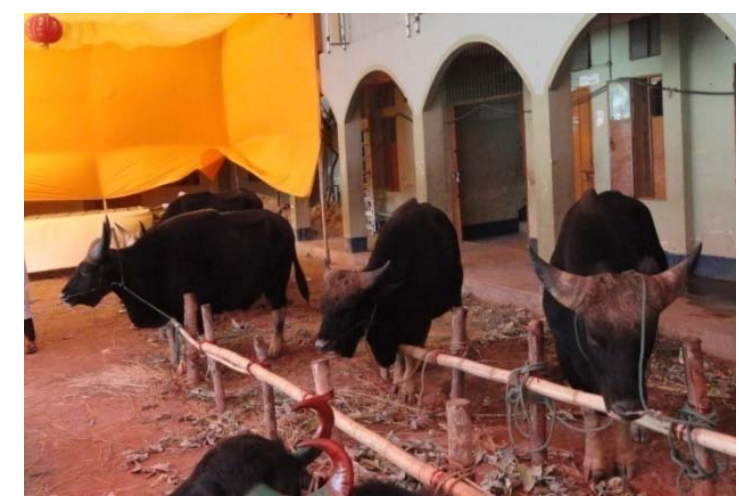

Plate 9. Gayal kept for selling

During this study period, 55 Gayal bulls were found to be sold for the "Oros" in Chittagong district. There was great variation for the price paid to farmers and gayal sold in "Oros". One mature bull was sold @ Tk. 1,20,00.00 to Tk. $1,50,000.00$ in the home tract. That was sold up to Tk. 3,00,000.00 in the "Oros" place. There were three types of middle man involved in the whole marketing operation. First set of middle man purchased the gayal in the local village, the second set middle man purchased the gayal from first middle man and carried to Chittagong or nearby area of Chittagong, the third middle man purchased the gayal from second middle man and kept in Chittagong or nearby area of Chittagong until the gayal was sold to "Oros".

\section{Problem in production and marketing}

The deceasing forest area and restriction of grazing in confined forest area was the main problem associated with gayal production. The lack of veterinary service as well as extension service of the government was the secondary problem. The absence of livestock market was the last problem observed during this study.

\section{Discussion}

The present study is the first of its kind on gayal in the home tract of Bangladesh. The study reveals that gayal is, nowadays, found in a limited geographical area in Bangladesh. It lives in forest near the Bangladesh Myanmar boarder. In fact, gayal could be observed at lower altitude (300 m) near Bandarban Sadar 25 years ago (Faruque et al. 1985; Furer-Haimendorf, 1980). They were also observed in the forest of Rangamati Hill district and Khagrachhari Hill district. However, gayal has been pushed to the deep forest in Bandarban Hill district nowadays near Bangladesh Myanmar Boarder due to deforestation and human settlement as well as converting the forest land in to the fruit garden. Therefore, the number of gayal has been reduced extremely and total number is now less than 1000 (about 850-900). So gayal is an endangered species in Bangladesh. The number of gayal in India and Myanmar is 260000 and 3000, respectively (Mondal et al. 2014). In china, the number of gayal is around 3000 (Yang et al. 2011). Gayal lives in forest having altitude as low as $150 \mathrm{~m}$ (Wungchuk et al. 2004) and as high as $3000 \mathrm{~m}$ (Mondal et al. 2014). Gayal prefers high altitude, hilly terrains of high slopes, dense forest to avoid direct sunlight and high rainfall area where plenty of fodder trees and shrubs are available. In Bangladesh, present inhabitant of gayal is located in an altitude of 800 to $1100 \mathrm{~m}$ and this area is hilly covered by deep forest. Such ecology and habitats for gayal in India, Bhutan, Myanmar, and China have been reported by Sanderson (1907), Schumann (1913), Hermanns (1952), Simoons and Simoons (1968), Brauns 
and Loffler (1986), Scherf (2000), Tanaka et al. (2011) and Yang et al. (2011).

The conformation and morphology of gayal of the present study indicates that most of the gayal in the home tract is pure. There are also some hybrids (gayal $x$ native zebu cattle). The body conformation and coat colour of gayal resembles to those of Bhutan, China and Myanmar. It resembles to gayal of Mizoram and Nagaland of India but differs to gayal of Arunachal of India. The gayal of Arunachal of India is white in colour (Arora 1998; Bhusan et al. 2000). Majid et al. (1995) reported the body length, height at wither, head length and head width of male gayal in Bangladesh Livestock Research Station to be $156.5 \mathrm{~cm}, 135.0 \mathrm{~cm}, 49.5 \mathrm{~cm}$ and $23.5 \mathrm{~cm}$, respectively. The body length in the present study was less than that reported by Majid et al. (2001). However, it is almost similar to the report of Gupta et al. (1996). Gupta at al. (1996) reported that body length of adult male and female gayal in India was $138.75 \mathrm{~cm}$ and $126.75 \mathrm{~cm}$, respectively. On the other hand, the head wide of gayal was more in the present than that reported by Haque et al. (2001). The true gayal has always wider forehead as reported by Sanderson (1907), Schumann (1913), Hermanns (1952), Simoons and Simoons (1968), Arora (1998) and Bhusan et al. (2000). This is also evidence from the plate $5 \mathrm{~b}$. The birth weight and body weight of gayal in the present study is more or less similar to the findings of Islam et al. (1993), Haque el al (2001), Mondal et al. (2014). The birth weight and mature weight of the gayal in the present study indicated that the daily growth rate of gayal was quite high and similar to those reported by other investigators like Haque at el. (2001), Arora (1998), Bhusan et al. (2000) and Mondal et al. (2014).

The reproductive efficiency of gayal in the home tract was high as indicated by calving interval (402 days). Mondal et al. (2014) reported the calving interval of gayal in India as 350 to 400 days. On the other hand, Haque at al. (2001) reported the calving interval of gayal ex-situ in Bangladesh as 553 days. This indicates that gayal in the home tract had optimum reproductive efficiency as compared to gayal in ex situ. The management differences in two systems have resulted in such difference. Another notable finding of the present study is that gayal in home tract had more disease resistant compared to gayal ex-situ. This was indicated by the health of gayal in-situ and also by PCV and $\mathrm{Hb}$ value. The gayal in-situ had higher PCV (36\%) and $\mathrm{Hb}(12$ $\mathrm{g} / \mathrm{dl}$ ) as compared to gayal ex situ (PCV (34\%) and $\mathrm{Hb}(7 \mathrm{~g} / \mathrm{dl})$. This difference was significantly higher $(p<0.05)$.

The gayal of Bangladesh is used only as meat animal as the milk yield is very low. On the other hand, the female gayal hybrids have been proved good milk producer and used extensively in the northeastern hilly areas of India and also in Bhutan (Mondal et al. 2014; Phanchung and Roden 1996). However, such hybrids could not generate any satisfactory result in Bangladesh (Haque et al. 2001). In absence of milk yield and draught utilization, gayal is used only as meat animals nowadays.

Gayal prefers cool place and browses herbs and grasses in the forest. This behaviour of gayal makes it difficult to get the optimum environment in the home tract. The forest area is reducing day by day due to deforestation of human settlement as well as use of more forest land for crop and fruit cultivation. On the other hand, there is no support service from the local or central government a present for the gayal. These are the problems to increase the number of gayal in home tract in Bangladesh.

\section{Conclusion}

Gayal is a valuable animal genetic resource and also an endangered animal species of Bangladesh. The growth rate and reproductive efficiency of gayal in the home tract and the utilization of gayal hybrids economically in India and Bhutan indicates that this species can be conserved and used economically in Bangladesh if a well planned breeding program combined with sound extension service can be made and executed.

\section{Acknowledgement}

The authors are grateful to Bangladesh Academy of Science (BAS-UDA-PALS) and Japanese Government (Monbushou) for the financial 


\section{Status of Gayal in Bangladesh}

support; Department of Livestock, Royal Government of Bhutan and Department of Livestock Services, Bangladesh specially the local Livestock Officers and Staffs for technical support, Bangladesh Agricultural University and gayal farmers for logistic support. Special thanks to Mr. Dyamoi Tonchanga, Bandarban Hill district for his active support and participation throughout the study period.

\section{References}

Arora CL (1998). Less used animal: Yak and Mithun - an over view. Indian Journal of Animal Science. 68: 735-742.

Bhusan S, Sharma D, Bujarbaruah KM, Singh RV (2000). Annual Report, National Research Centre on Mithun, Jharnapani, Nagaland 797106: 4-10.

Brauns C, Loffler LG (1986). Mru-Hill people on the boarder of Bangladesh - Birkhauser Verlag, Berlin.

Cable RM (1957). An Illustrated Laboratory Manual of Parasitology, $4^{\text {th }}$ edn., Burges Publishing Co., Minneapolis 15, Minnesota, USA.

Faruque MO, Ahmed A, Mostafa KG (1985). Some observations on the livestock in Chittagong division of Bangladesh. Livestock Advisor, 10: 41-44.

Faruque MO, Hasnath MA, Khan YMYA, Takashi Y, Nomuar K, Amano T (2009). Current status of animal genetic resources and livestock population in Bangladesh. Report Society for Research on Native Livestock J apan, 25: 1-33.

Gupta N, Gupta SC, Verma ND, Pundir RK, Joshi BLK, Nivsarkar AE, Sahai R (1996). Mithun, an important bovine species of Indian origin. Animal Genetic Resources Information, 18: 41- 49.

Furer-Haimendore C (1980). A Himalayan tribe from cattle to cash. University of California press, Los Angles.

Haque KS, Jalil MA, Rahman MM (2001). Development of beef cattle breed using gayal (Bos frontalis). Research report of Bangladesh Livestock Research Institute, Savar. P. 45.

Hermanns M (1952). Where animal first domesticated and bred in India? Journal
Bombay Branch of the Royal Asiatic Society, 27: 134-173.

Hickman CG, Tenzin D (1982). The classical crossbreeding systems in Bhutan. Bhutan J ournal of Animal Husbandry, 5:19-22.

I slam NN, Mia MM, Islam MM (1993). Study on the production potential of gayal in Bangladesh. Bangladesh Journal of Animal Science, 22: 113-118.

Li SP, Chang H, Ma GL, Cheng HY. 2008. Molecular phylogeny of the gayal in Yunnan china inferred from the analysis of cytochrome b gene entire sequences. AsianAustralasian Journal of Animal Sciences, 21: 789-793.

Majid MA, Mia MM, Talukder Al (1995). Development of gayal Friesian breeding in Bangladesh. Progress report. Animal Production Research Division, Bangladesh Livestock Research Institute, Savar.

Mason IL. 1988. World Dictionary of Livestock Breeds, 3rd Edition. CAB International, Wallingford.

Namikawa T, Amano T, Okada I, Hasnath MA, Haque AKF, Majid MA (1987). Karyotype, blood groups and blood protein polymorphisms in the gayal, gayal-hybrid and native cattle of Bangladesh. In: Genetic studies on breed differentiation of the native domestic animals in Bangladesh, Part II. Edn. Okada I. Hiroshima University, P. 105-115.

Payne WJA, Hodges J (1997). Tropical Cattle: Origins, Breeds and Breeding Policies. Blackwell Science Limited, Oxford. P. 328

Phanchung, Roden JA (1996). Characterization of the Siri breed and the mithun cross Siri in Bhutan. Animal Genetic Resources Information, 20: 27-34.

Scherf BD. 2000. Word Watch List for Domestic Animal Diversity, 3rd Edn. Food and Agriculture Organization of the United Nations, Rome.

Schumann H. 1913. Gayal und gaur und ige gegenseitigen Beziehumgen. Kuhnarchiv , 3 7-80.

Simoons FJ, Simoons ES (1968). A ceremonial ox of India. The mithun in nature, culture, and history. The University of Wisconsin Press, Madison.

Snadecor GW, Cockran WG (1980). Statistical 
methods, $7^{\text {th }}$ edi. The Iowa State University Press, Ames, Iowa, USA

Sanderson GP (1907). Thirteen Years among the wild beasts of India: Their haunts and habits from personal observation (6th ed.). John Grant, Edinburgh. P. 243-265

Tanaka K, Takizawa T, Murakoshi H, Dorji T, Nyunt MM, Yoshio M, Yamamoto $T$, Namikawa T (2011). Molecular phylogeny and diversity of Myanmar and Bhutan mithun based on mtDNA sequences. Animal Science J ournal, 82: 52-56.

Yang SL, Gao Z, Mao HM, Deng WD, Wu XC (2011). Biological characteristics and rumen ricroorganisms of gayal (Bos frontalis) in
Yunnan province. Agricultural Science and Technology, 12: 1234-1237.

Winter H, Mayr B, Schleger W, Dworak E, Krutzler J, Kalat M (1986). Genetic characterization of the Mithun (Bosfrontalis) and studies of the spermatogenesis, blood groups and aemoglobulins of its hybrids with Bos indicus. Research in Veterinary Science, 40: 8- 17.

Wangchuk T, Thinley P, Tshering K, Tshering C, Youten D, Pema B, Wangchuknn S (2004). A field guide to the mammals of Bhutan. Department of Forestry, Ministry of Agriculture, Thimphu, Bhutan. P. 98-99. 